Bożego, godzina biblijna, spotkania biblijne (metoda Martiniego i Mestersa). Część praktyczna zawiera materiały do wykorzystania w czasie różnych nabożeństw i spotkań.

Książka została napisana w oparciu o doświadczenie duszpasterkie diecezji tarnowskiej, gdzie na zarządzenie nowego biskupa została w styczniu $1991 \mathrm{r}$. przeprowadzona w całej diecezji niedziela biblijna. Książka może służyć jako pomoc w przeprowadzeniu niedzieli biblijnej, tymbardziej, że tekst roboczy II Polskiego Synodu Plenarnego proponuje wprowadzenie w każdej parafii niedzieli biblijnej oraz tygodnia biblijnego (por. Biblia-Sobór-Życie, IV,3).

Kraków

KS. JERZY CHMIEL

\title{
POLSKIE QUMRANICA (przegląd)
}

Bez żadnej przesady i obawy o megalomanię można mówić o polskich qumranikach, czyli publikacjach w Polsce wydawanych na temat wykopalisk znad Morza Martwego (nie tylko Qumran). Inicjatorem tych edytorskich przedsięwzięć jest dr Zdzisław Jan $\mathrm{K}$ a p e r a, krakowski orientalista i edytor, organizator trzech międzynarodowych kolokwiów nt. odkryć nad Morzem Martwym, które to spotkania miały miejsce w Krakowie-Mogilanach w latach: 1987, 1989 i 1991 (zob. sprawozdania w RBL). Polska staje się w ten sposób jakby centrum badań czy spotkań kumranologicznych. Ważną rzeczą jest publikowanie w językach kongresowych, co pozwala na nawiązywanie i utrzymywanie kontaktów z całą nauką światową.

I. Została założona seria QUMRANICA MOGILANENSIA, która obejmuje dwie podserie: A. Publikacje książkowe (Pamphlets and Books) i B. biuletyn ,The Qumran Chronicle".

A. Publikacje książkowe QM:

Vol. 1. H.H. B u rg m a n ner, ,Sitz im Leben” in den Josuafluch-Texten in $4 Q 379$ 22 II und 4Q Testimonia, Kraków-Offenburg 1990, ss. 64. Autor (1914-1992), wybitny kumranolog, związany pierwotnie z tzw. szkołą marburską, a potem działający indywidualnie, uczestniczył aktywnie w mogilańskich spotkaniach kumranologicznych. W recenzowanej pracy zostały omówione dwa teksty związane z klątwą Jozuego (zob. Joz 6,26) i zachowane w dwóch odrębnych dokumentach znalezionych w Qumran. Wiąże się to z zamordowaniem machabejskiego kapłana Szymona i jego synów w r. 134 przed Chr. oraz późniejszą interpretacją tych faktów.

Vol. 3. Mogilany 1989. Papers on the Dead Sea Scrolls offered in memory of Jean Carmignac. Part II: The Teacher of Rightrousness - Literary Studies, Kraków 1991, ss. 244. Została tutaj pomieszczona część materiałów z II Międzynarodowego Kolokwium Qumranologicznego dotycząca „Nauczyciela Sprawiedliwości”, jak również inne referaty. Część II materiałów z tego mogilańskiego spotkania kumranologów w 1989 r., poświęconego pamięci wybitnego znawcy zagadnień z Qumran, ks. Jeana Carmignaca (1914-1986), znajdzie się w vol. 2 QM (w druku).

Vol. 5. H. B u rg m a n n, Die Geschichte der Essener von Qumran und „Damaskus”, Kraków-Offenburg 1990, ss. 180, ilustr. i ryc. Jest to historia esseńczyków pióra zmarłego w r. 1992 znanego kumranologa i religiologa.

B. Biuletyn „The Qumran Chronicle”, Cracow.

No. 1. August 1990. Zawiera artykuły i streszczenia (Abstracts) referatów wygłoszonych na II Międzynarodowym Kolokwium Qumranologicznym w Krakowie-Mogilanach 1989.

No. 2. Appendix „A”. December 1990. Przedruk anonimowej prepublikacji (tekst hebrajski i przekład angielski) słynnego od paru lat rękopisu Miqsat Ma'aseh ha-Torah z groty 4 Qumran (4Q MMT).

No. 2/3. December 1990/April 1991. Qumran Cave IV and MMT. Special Report, Kraków 1991, ss. 120, ilustr.

Specjalnie przygotowana przez Z.J. Kaperę praca zbiorowa omawiająca „sensacje” związane $\mathrm{z}$ rękopisem MMT (którego tekst i przekład został pomieszczony w nrze 2, 
Appendix „A”) w kontekście znalezisk groty 4Q, przed sesją w Mogilanach w $1991 \mathrm{r}$.

II. Tematykę kumrańską zawierają niektóre woluminy naukowego rocznika orientalistycznego „Folia Orientalia”, organu Komisji Orientalistycznej PAN — Oddział w Krakowie, w którym teksty są publikowane tylko w językach kongresowych.

Vol. XXV, 1988 zawiera materiały z I Międzynarodowego Kolokwium Qumranologicznego w Krakowie-Mogilanach 1987.

Vol. XXVI, 1989. Dział Qumranica, w którym zostały pomieszczone artykuły i omówienia H. Burgmanna. Z.J. Kapery, E. Lipińskiego i P. Muchowskiego.

Vol. XXVII, 1990. Prace Z.J. Kapery i H. Burgmanna na tematy kumrańskie, jak również przedruk artykułów na temat imion Boga Jahweh i Elohim pióra śp. ks. Aleksego Klawka (1890-1969) z okazji stulecia jego urodzin oraz artykuły: śp. J. Carmignaca (o teologii Magnificat) i J. Riauda (Paralipomena Jeremiasza).

III. „Filomata” - czasopismo założone w r. 1929 przez prof. R. Gansińca, poświęcilo dwa numery specjalne rękopisom znad Morza Martwego. Redaktorem tych numerów jest Z.J. Kapera pełniący równocześnie funkcje sekretarza redakcji czasopisma.

Nr 391 (1989) zawiera omówienie rękopisów z Qumran (J. Chmiel, W. Chrostowski, Z.J. Kapera, S. Mędala).

Nr 395 (1990) poświęcony jest odkryciom archeologicznym znad Morza Martwego (W. Chrostowski, Z.J. Kapera, S. Mędala).

Oba zeszyty „Filomaty” ilustrowane reprodukcjami oryginalnych zdjęć J.C. Trevera, członka Amerykańskiej Szkoły Badań Orientalnych w Jerozolimie.

Publikacje do nabycia w: The Enigma Press. Z.J. Kapera, ul. Borsucza 3/58, PL 30-408 Kraków.

Kraków

KS. JERZY CHMIEL

\section{PRZEGLAQD BIBLIOGRAFICZNY}

\section{ATENEMUM KAPŁAŃSKIE}

1991, t. 117, z. 2-3

Muszyński H., bp, „Dziesięć prostych Stów Boga” zwanych Dekalogiem, 221-233

1992 , t. 118, z. 2

Haręzga St., ks., Biblijna parresia i jej aktualność w świetle encykliki „Redemptoris missio", 293-306

\section{COMUNIO}

1989, z. 3

Kobielus St., SAC, Niebiańska Jerozolima miejscem szczęścia, 119-127

1989, z. 4

Zeller D., Izrael wobec Bożego wezwania, 30-43

1992, z. 1

Luzarraga J., SJ, Życie wieczne w pismach św. Jana, 24-35

1992, z. 2

Lehmann K., bp, Problem biblijnego świadectwa o bierzmowaniu, 12-19;

Radl W., Bierzmowanie w Nowym Testamencie, 3-12 